\title{
A NEW SPECIES OF LIGYRA NEWMAN FROM RORAIMA, BRAZIL (DIPTERA, BOMBYLIIDAE, ANTHRACINAE)
}

\author{
Carlos José Einicker Lamas ${ }^{1}$ \\ Márcia Souto Couri ${ }^{1}$
}

\begin{abstract}
Ligyra maracaensis, sp.n. (from Brazil, Roraima, Maracá Island) is described.

KEY WORDS. Diptera, Bombyliidae, Anthracinae, Ligyra, taxonomy
\end{abstract}

The neotropical genus Ligyra Newman, 1841, comprises 19 species and two subspecies (PAINTER et al. 1978). It was recently placed in Anthracinae by YATES (1994).

Almost all neotropical species were revised by PAINTER \& PAINTER (1974), except L. dido (Osten-Sacken, 1886); L. gazophylax (Loew, 1869); L. orcus (Walker, 1849) and L. pilatei (Macquart, 1846), and L. alacer and L. evansi described by Painter in PAINTER \& PAINTER (1969).

Studying material from the Museu Paraense Emílio Goeldi (Pará, Brazil), the authors found a new species of Ligyra, wich is herein described and illustrated.

\section{Ligyra maracaensis, sp.n.}

Fig. 1

Holotype female. Brasil, Roraima / Ilha Maracá - Malaise [Trap] / 22-XI-1978 / Col. I.S. Gorayeb. Holotipo [red label]. Ligyra maracaensis Lamas \& Couri. (MNRJ) [Museu Nacional, Rio de Janeiro]. In good conditions; left hind leg without tarsomeres and right hind leg broken in the end of femur. Paratypes. Same label as holotype: two females (MNRJ); 27-XI-1978, four females (two at MNRJ and two at Museu Paraense Emilio Goeldi). Paratypo [green label]. Ligyra maracaensis Lamas \& Couri. All in good conditions.

Diagnosis. Ground color predominatly black; wing dark brown, only tip hyaline; the vein between trhe first posterior cell and the third submarginal cell delimits the hyaline and brown areas at this point; a brown spot at apical portion of vein R2 +3; center of posterior cells light brown; a whitish spot in upper apical third of discal cell (Fig. 1). Margin of scutellum with long and strong black bristles; postalar callus with three long and strong and some shorter black bristles; katatergite with orange hairs in the upper third and along posterior margin; metakatepisternum with orange pile in center.

1) Museu Nacional, Universidade Federal do Rio de Janeiro, Quinta da Boa Vista, 20940-040 Rio de Janeiro, Rio de Janeiro, Brasil. Bolsista do CNPq. 


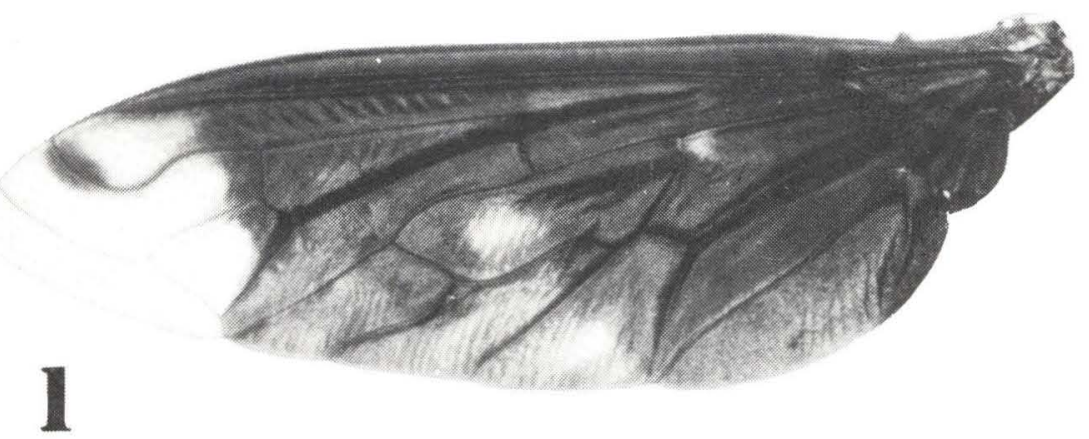

Fig. 1. Ligyra maracaensis. Holotype: wing.

Description. Female. Body length: 16mm; wing: 18mm. Head: frons black, face brown and gena light brown; face projected, about as long as antennal length without style; proboscis with only labella exceeding mouth opening; palpus with black hairs; face and frons clothed with short black hairs; occiput with short black hairs and silver scales; occipital fringe yellow; antennae brown with first two articles with black hairs; first article about 2.5 times length of second, which is as long as broad; third article conical, elongated, about as long as first two together; style a little shorter than third article. Thorax: black; scutellum brown; short black hairs dorsally, longer at margins; thoracic ruff orange; scutellar margin with long and strong black bristles; post-alar callus with three long and strong and some shorter black bristles; anepisternum clothed with brown hairs, in the upper portion many orange ones; katepisternum with sparse brown hairs; anepimeron and meron bare; katatergite with orange hairs in the upper third and along posterior margin; metakatepisternum with orange pile in center. Legs: hairs, bristles and scales black; anterior pair without bristles. Wing: dark brown, only tip hyaline; vein between first posterior cell and third submarginal cell delimiting the hyaline and brown areas at this point; a brown spot at apical portion of vein $\mathrm{R} 2+3$; center of posterior cells light brown; a whitish spot in upper apical third of discal cell (Fig. 1). Abdomen: black, with brown spots on sides of second abdominal tergite; clothed with short black hairs at dorsum, longer laterally; tergites II-IV and VI-VII with patches of silvery scales in each side, the remainder of these tergites and entire tergite $\mathrm{V}$ clothed with black scales.

Discussion. The color pattern of the wing easily seggregates this species from all others in the genus.

ACKNOWLEDGMENTS. We are grateful to Prof. Therezinha P. de Jesus Chaves (Diptera Curator - Museu Paraense Emilio Goeldi) for the loan of the material, and also to Dr. S. Fragoso (Museu Nacional, Rio de Janeiro) for the photographs. 


\section{REFERENCES}

PAinter, R.H. \& E.M. PAinTeR. 1969. New Exoprosopinae from Mexico and Central America (Diptera: Bombyliidae). Jour. Kansas Ent. Soc. 42: 5-34.

- 1974. Notes on, and redescriptions of, types of South American Bombyliidae (Diptera) in European and United States Museums. Res. Publ. Kansas State Univ. Exp. Stat. 168: 1-322.

PainTer, R.H.; E.M. PainTer \& J. Hall. 1978. A Catalogue of Diptera of the Americas South of the United States. Family Bombyliidae. São Paulo, Universidade de São Paulo, Departamento de Zoologia, p.1-92.

YATES, D.R. 1994. The cladistics and classification of the Bombyliidae (Diptera: Asiloidea). Bull. Am. Mus. Nat. Hist. 219: 1-191.

Recebido em 30.VIII.1994; aceito em 08.II.1995. 